\title{
Antibacterial and Cytotoxic Activities of the Leaf Extract of Holigarna longifolia Roxb.
}

\author{
A.E. Ekram and K.M.F. Hoque \\ Department of Genetic Engineering and Biotechnology, University of Rajshahi, Rajshahi-6205, Bangladesh.
}

The cloroform extract of the leaf of Holigarna longifolia was tested against the brine shrimp, Artemia salina naupli for cytotoxic activity through dose-mortality assay which offered $\mathrm{LC}_{50}$ values of $23.059 \mu \mathrm{g} / \mathrm{ml}$ and the regression equation was $\mathrm{Y}=$ $1.1128+4.4853 \mathrm{X}$, while the $95 \%$ confidence limits are 19.590 to $27.142 \mu \mathrm{g} / \mathrm{ml}$ for 24 hour of exposure. In case of antibacterial screening, crude extract of $H$. longifolia leaf was applied against a number of Gram positive (Bacillus megaterium, B. subtilis, Sarcina lutea, Streptococcus- $\beta$-haemolyticus, St. aureus) and Gram negative (Salmonella typhi, Shigella boydii, Sh. sonnei, Sh. dysenteriae, E. coli and Pseudomonus aeruginosa) bacteria. From the recorded zone of inhibition it is obvious that $H$. longifolia extract is effective against Gram positive bacteria such as Bacillus megaterium (QL-38), Sarcina lutea (QL166), B. subtilis (QL-40) but little active against Gram negative bacteria such as Pseudomonus aeruginosa.

More than 500 species of medicinal plants are estimated as growing in Bangladesh and about 250 species of them are used for the preparation of traditional medicines. However, the majority of these plants have not yet undergone chemical, pharmacological and toxicological studies to investigate their bioactive compounds. ${ }^{1}$ Traditional records and ecological diversity indicate that Bangladeshi plants represent an exciting resource for

Correspondence to: K.M.F. Hoque

E-mail: kmfhoque03_gen@yahoo.com

Dhaka Univ. J. Pharm. Sci. 12(1): 83-85, 2013 (June) possible lead structures in drug design. For example, a few studies into the anticancer potential of plants used in Bangladeshi folk medicine have been performed. ${ }^{2}$ A number of flavonoids and polyphenols have previously been isolated from Hygrophila auriculata, Bruguiera gymnorrhiza, Clerodendron inerme, Blumea lacera, Hibiscus tiliaceous and Aegiceras corniculatum, growing in Bangladesh, ${ }^{3}$ which may be involved in their reported cytotoxic activity. Antibacterial activity (Adiantum caudatum, Ficus religiosa, Mollugo pentaphylla and Argemone mexicana) has been also reported. ${ }^{4} \mathrm{H}$. longifolia was selected in this investigation for being a family member of Anacardiaceae because of the plants of this family possess anticancer properties and still remain in unexplored condition. $H$. longifolia (Synonym: Holigarna arnottiana) is locally known as Borola/ Katebel. This is a plant growing in the south-east of Bangladesh (Chittagong, Cox's Bazar and Chittagong Hill Tracts) and is reported in Lloydia to have antitumour properties. ${ }^{5}$ Since this plant has various medicinal properties so the present study was undertaken to evaluate the cytotoxic and antibacterial activities of cloroform extract of leaf of $\mathrm{H}$. longifolia systematically for this first time.

The plant materials were collected from Chittagong hill tracts area and experiments were done in the Microbiology Laboratory, Department of Genetic Engineering and Biotechnology, Rajshahi University. Brine shrimp lethality ${ }^{6}$ is a recent development in the bioassay for the bioactive compounds, which indicates cytotoxicity as well as wide range of pharmacological activities (e.g. 
anticancer, antiviral, pesticidal, anti-HIV etc.) of the compounds. Since the lethality test involves the culture of brine shrimp, Artemia salina nauplii, the nauplii should be grown in the sea water. Sea water contains $3.8 \%$ of sodium chloride. Accordingly, 3.8\% sodium chloride solution was made by dissolving 38 gm sodium chloride in $1000 \mathrm{ml}$ distilled water and filtered off. The $\mathrm{pH}$ of the brine water thus prepared was maintained between 8 and 9 using $\mathrm{NaHCO}_{3}$. Constant temperature $\left(37^{\circ} \mathrm{C}\right)$ and sufficient light were ensured to give sufficient aeration. After 48 hours, matured shrimp as nauplii (larvae) was collected and 30 nauplii were used for each concentration $(\mu \mathrm{g} / \mathrm{ml})$ of the experiment. For the sample extract, $200 \mu \mathrm{g}$ were initially dissolved in $100 \mu \mathrm{l}$ of pure dimethyl sulfoxide (DMSO) to make hydrophilic before adding $1.9 \mathrm{ml}$ of water to get a concentration of 200 $\mu \mathrm{g} / \mathrm{ml}$ which was used as stock solution-A. Then a series of dilution was made to provide $100 \mu \mathrm{g} / \mathrm{ml}, 50$ $\mu \mathrm{g} / \mathrm{ml}, 25 \mu \mathrm{g} / \mathrm{ml}, 12.5 \mu \mathrm{g} / \mathrm{ml}, 6.25 \mu \mathrm{g} / \mathrm{ml}, 3.125$ $\mu \mathrm{g} / \mathrm{ml}, 1.562 \mu \mathrm{g} / \mathrm{ml}, 0.78125 \mu \mathrm{g} / \mathrm{ml}$ and $0.3906 \mu \mathrm{g} / \mathrm{ml}$. For each concentration, one test tube containing the same volume of DMSO diluted up to $10 \mathrm{ml}$ with seawater and 30 shrimp nauplii was used as negative control group. It was used to verify the validity of the test. After 24 hours, the test tubes were observed that the number of survived nauplii in each test tube was counted and the result was calculated by probit analysis to determine $\mathrm{LC}_{50}$.

The antibacterial assay was performed in vitro by the disc diffusion assay method. ${ }^{7}$ Fifteen pathogenic bacteria were selected for the test and pure culture of these bacteria were collected from the Department of Microbiology and Institute of Nutrition and Food Science (INFS), University of Dhaka and later cultures were maintained in the Institute of Biological Sciences, University of Rajshahi. For experimental purpose, sterilized filter paper discs $(6 \mathrm{~mm}$ in diameter) were taken by the forceps in the plates. Crude extracts of chloroform $(50 \mu \mathrm{g} / \mathrm{disc}$ and 200 $\mu \mathrm{g} / \mathrm{disc})$ were applied on the discs with the help of a micropipette in an aseptic condition. These discs were left for a few minutes in aseptic condition for complete removal of the solvent. Cyprofloxacin (30 $\mu \mathrm{g} / \mathrm{disc})$ was used as standard disc for comparison purpose. Finally, the plates were incubated at $37.5^{\circ} \mathrm{C}$ for 24 hours in an incubator. The discs were placed in such a way that they were not closer then $15 \mathrm{~mm}$ to the edge of the plate and enough apart to prevent over lapping the zones of inhibition. After incubation, the antibacterial activity of the test samples was determined by measuring the diameter of inhibitory zones in term of mm with a transparent scale.

Table 1. Probit mortality of $A$. salina (nauplii) by $\mathrm{CHCl}_{3}$ extract of $\mathrm{H}$. longifolia exteract after 24h of exposure. $\mathrm{Y}=-1.112843+4.485354 \mathrm{X}$

\begin{tabular}{lllllllllll}
\hline Dose $(\mu \mathrm{g} / \mathrm{ml})$ & Log dose & Number & Killed & \% killed & Corr \% & $\begin{array}{l}\text { Emp } \\
\text { probit }\end{array}$ & $\begin{array}{l}\text { Expt } \\
\text { probit }\end{array}$ & $\begin{array}{l}\text { Wrk } \\
\text { probit }\end{array}$ & Weight & $\begin{array}{l}\text { Final } \\
\text { probit }\end{array}$ \\
\hline 50.00 & 1.699 & 30 & 29 & 96.667 & 94 & 6.55 & 6.538 & 6.528 & 8.07 & 6.508 \\
25.00 & 1.398 & 30 & 23 & 76.667 & 56 & 5.15 & 5.173 & 5.140 & 19.02 & 5.157 \\
12.50 & 1.097 & 30 & 16 & 53.333 & 12 & 3.82 & 3.808 & 3.822 & 11.10 & 3.807 \\
\hline
\end{tabular}

Chi-squared is 1.156998E-02 with one degree of freedom. No significant heterogeneity was found. $\log \mathrm{LC}_{50}$ is $1.362845 \quad \mathrm{LC}_{50}$ is $23.05925 ; 95 \%$ confidence limits are 19.59007 to 27.14279

In case of cytotoxicity test, $\mathrm{LC}_{50}$ for $\mathrm{H}$. longifolia leaf extract was $23.059 \mu \mathrm{g} / \mathrm{ml}$ and the regression equation was $\mathrm{Y}=-1.1128+4.4853 \mathrm{X}$, while the $95 \%$ confidence limits were 19.590 to $27.142 \mu \mathrm{g} / \mathrm{ml}$ for 24 hour of exposure (Table 1). The $\mathrm{LC}_{50}$ values were calculated with probit analysis software (LdP Line software, USA). In case of antibacterial activity, from the recorded inhibition zones (data not presented in table) it is obvious that $H$. longifolia leaf extract is mildly effective against Gram positive bacteria such as Bacillus megaterium ( $7 \mathrm{~mm}$ ), Sarcina lutea (7 $\mathrm{mm})$, Bacillus subtilis $(10 \mathrm{~mm})$ Gram negative bacteria Pseudomonus aeruginosa (7 mm). However, no activity was observed against Shigella boydii, Shigella sonnei, Shigella dysenteriae and E. coli.

It can be inferred from the obtained results that the extract showed weak antibacterial activity against some of the pathogenic bacteria tested here. However, 
the extract was found to be lethal to the aqualic organism, A. salina. In the present investigation, it may be concluded that attempts should be taken to isolate and characterize bioactive principles to develop new leads of therapeutic interest and to cure various human ailments.

\section{REFERENCES}

1. Ghani, A.2003. Medicinal Plants of Bangladesh with Chemical Constituents and Uses, Asiatic Society of Bangladesh, Dhaka, Bangladesh,

2. Costa-Lotufo, L. V, Khan,M. T. H, Ather, A. 2005 Studies of the anticancer potential of plants used in Bangladeshi folk medicine, J. Ethnopharmacology. 99, 21-30.

3. Uddin, S. J, Shilpi, J. A, Alam, S. M, Alamgir, M, Rahman, M. T. and Sarker, S.D. 2005. Antidiarrhoeal activity of the methanol extract of the barks of Xylocarpus moluccensis in castor oil- and magnesium sulphate-induced diarrhoea models in mice. J. Ethnopharmacol. 101, 139-143.
4. Singh, M. N, Khare, P. B. and Rawat, A. K. S. 2008. Antimicrobial activity of some important Adiantum species used traditionally in indigenous systems of medicine. $J$. Ethnopharmacol. 115, 327-329.

5. Hartwell, J.L. 1970. Plants used against anticancer. A survey. Lloydia 33, 180-182.

6. Meyer, B.N, Ferrigni, N.R.J, Putnam, E.L, Jacobsen, B, Nichols, D.E. and McLaughlin, J. 1982. A convenient general bioassay for active plant constituents. Planta Med. 45, 31-34.

7. Barry,C, Ahmed, A. and Khan, A. A. 1976. Endemic filiriasis in Thakurgaon, East Pakistan. Amer. J. Trop. Med. Hyg. 22, 592-597 